\title{
Dynamic types of artistic image: Roman Ingarden's phenomenology and literary theory
}

\author{
Anastasia A. Aksenova \\ Kemerovo State University \\ 6 Krasnaya St, Kemerovo, 650000, Russian Federation
}

\begin{abstract}
The article is devoted to the question of some data obtained by Polish philosopher Roman Ingarden, and primarily to his study of the literary work of art. Development upon Ingarden's ideas is associated with use of Russian authors which are rarely treated in phenomenological aesthetics. The dynamic types of the image structure is that appear as potential states and actualize themselves in the reader's reception as problem of imageability of fictional entities. Thus the dynamic character of types of an image structure is a transition from non-thematic background into its actual state and back. To study the visual in fiction, one must understand that the reader's encounter with the literary work actualizes potential types, which, according to R. Ingarden, "sparkle and go out". The visual nature of the aesthetic object directly depends on which of these potential states are actualized.
\end{abstract}

Keywords: aesthetic object, receptive act, artistic world, reader, types of image structure, imagination, representation, B. Pasternak, Y. Olesha

\section{Introduction}

The need for a scientific understanding of the visual in various arts first manifested itself in Jean-Battiste Dubot's "Critical Reflections on Poetry and Painting” (1719). He stated that Painting has a greater power over people than Poetry [1. P. 221]. The issue was further developed in G.E. Lessing's "Laocoon, or On the Limits of Painting and Poetry" (1766), where he strongly opposed the idea of equivalence of arts. Lessing wrote that painting depicts actions with the help of bodies while poetry should depict bodies indirectly, via the actions they perform. The poet wants to make the ideas he excites in us so vivid that we could believe that we actually perceived the depicted objects while completely forgetting about the tool the poet used for that, i.e. the word [2. P. 201].

Lessing clearly pointed to the obvious difference between the material and the ideal by placing the visual in fiction outside the objectivity of the book as a thing. This, however, does not mean that the spheres of the artistic world and the visual in fiction are completely inaccessible for cognition and scientific understanding. 
In art, reality transforms due to the visual character of the artistic image. According to G.-G. Gadamer, the language process is inherent to human beings: "the main mode of any linguistic process is being 'inside the word', when the word is no longer viewed as an object" [3. P. 37]. An aesthetically complete reception demands certain efforts of imagination from the reader. This is due to the specifics of the verbal image: there is a different approach behind the studies of the text structure as a whole and its semantic structure. This approach is otherwise oriented and poses a different problem. This is a hermeneutic approach. It begins with the realization that the language inevitably refers its user beyond itself, thus pointing to the boundaries of the linguistic form of expression [3. P. 46]. To perform and understand these efforts is a hermeneutic issue. The position of the visual in literature between the reality of the text and the reality of the reader itself prompts us to cite the thought of W. Iser: "A literary work appears when there is a combination of the text and the reader's imagination, and it is impossible to specify the point where this combination occurs" [4. P. 203].

From R. Ingarden's position, image representation is schematic: it is an incomplete set of known facts, objects, and circumstances. On the contrary, imagination concretizes the non-thematic background unspecified in the scheme (text) of the literary work. That is, the artistic world acquires its visual appearance according to the presentation of the images given to the reader and the actualization of the potential types specified by the imagination.

So, the understanding of the aesthetic phenomenon is not arbitrary. It occurs only when the reader is given facts or examples which foreground the aesthetic phenomena. Such examples can be obtained from objects of a more local character, if compared with the aesthetic itself, i.e. in fiction. Roman Ingarden to have been the first to explore this. Jeff Mitscherling in his 1985 article does not accidentally make a note: “Throughout my analyses, I employ Ingarden's terminology. For the reader who is unfamiliar with this terminology, and perhaps with Ingarden's work in general, these analyses must prove difficult to follow, if not entirely incomprehensible" [5. P. 351]. Understanding poetic texts is carried out against the background of understanding and human everyday life, and identifying "strange" places in the text becomes key to understanding the meaning.

The formation of the semantic sphere of an artistic image occurs in the context of value-based relationships in the artistic world. The transition to the artistic world, which is carried out in the reader's imagination, is accompanied by an oddity: the depicted world is translated from the sphere of realistic logic into a poetic language, organized according to the logic of art. The logic of the poetic world based on the combination of identity and lifelikeness: to be clear to the person the art is lifelikeness, but to point to the truth, it expresses a peculiar, illogical (from the standpoint of daily life) way.

In an act of reception, the properties of the aesthetic object manifest themselves as visible but elusive dynamic types of image structure. The dynamic type of the image structure is a transition from a non-thematic background into its actual state and back. 


\section{Some Russian-language sources that are close in their approach to the literary work to the views of Roman Ingarden}

In fiction studies, the aesthetic object is defined as an artistic world depicted in the book, which lies beyond the book as an object. According to M.M. Bakhtin, to implement an aesthetic object means to accomplish an artistic task in its essence.

It is a consistent transformation of a linguistically and compositionally comprehended verbal whole into an architectonic whole of an aesthetically complete event. In this process, all verbal connections, as well as linguistic and compositional relationships, are transformed into non-verbal architectonic event connections [6. P. 50]. This process is crucial for the present research: in fiction, the complete image of the world is represented by the text. At the same time, the image depends on the language and on the clash of different minds, both fictional (personages) and external (the author and the reader).

M.M. Bakhtin also points out the specifics of the aesthetic object: the main goal of verbal creativity is to overcome the verbal, i.e. the word, because the aesthetic object appears on the boundaries of the verbal, i.e. the boundaries of the language as such [7. P. 49]. In art, the verbal frontier does not simply copy a fragment of reality but creates a self-contained system, in which various images demonstrate an analogue of human life unfolded in the world. Thus, both the reader's imagination and the work of fiction are directed outward the text.

The receptive type of verbal activity is associated with receptuni (Latin), or receiving a visible verbal message. It refers to the conceptual and informative perception of graphic symbols, which - in the real world - depends on perception organs, or receptors. This research, however, is focused on a different aspect of reading where the main role is given not to the organs of perception, i.e. eyes-receptors, but to the organs of representation, i.e. reader's imagination. Such an aspect lies beyond the tangible objectivity of the book as a thing. The receptive aspect of the visual in fiction lies in the fact that the artistic world and its aesthetic connections come to life when the reader encounters the work of fiction. The artistic world and the life depicted by the author are awoken by the reader's life. Thus, the reader's insight into the artistic world actualizes it. In this case, it is not the receptive aspect of the aesthetic event that matters. When literary personages and their environment stop being a set of alphabetic characters, they become an aesthetic object, i.e. the image of a person living in a particular world. As soon as that happens, the aesthetic connections acquire a visible appearance in the form of the depicted world.

Here it is necessary to take into account the specifics of what is inherent to literature besides language, i.e. the sphere of the artistic world, which has its own visual structure. From the point of view of perception, this structure is determined mostly by the method the reader uses to enter the artistic world, i.e. by the process of representation reading. According to V.F. Asmus, the reader refers to what they read about or visualize by reading not as a complete fiction but as a kind of reality [8. P. 55]. This indicates the attitude to the world depicted by the author not as the environment around the reader, but as a world of fiction revealed in aesthetic relations, not in ethical ones. Aesthetic qualities are inherent to all layers and components of the work of fiction. These also include "metaphysical qualities", by which R. Ingarden 
meant such aesthetic categories as modes of fiction. The types are produced by the imagination of the recipient. The peculiarity of the phenomenological approach to art lies in the fact that, unlike other layers, the types do not form a continuous whole.

Outside the identification of the semantic structure of the text, the reader's consciousness has to make other efforts, such as imagination and the ability to see connections. According to L.Yu. Fukson, reading turns the word into an image, which means transition from the semiotic level of the text into an aesthetic reality aka artistic world. Such a transition requires an effort of imagination [9. P. 293].

The conditional nature of signs in verbal oeuvre places the visual outside the reader's world, while other forms of art provide a direct perception of the visual in the form of paint, body, stone, etc. This results in an assumption that literature is not only an art of indirect speaking [6. P. 289] but also an art of indirect vision. It is quite possible that the theoretical substantiation of the visual field owes its problems to the fact that the idea of synthesis of arts vs. the idea of their complete dissociation often alternated in the course of the history of thought.

There have been numerous studies of the visual in the oeuvre of individual writers, which indicates the relevance of the problem. E.L. Suzryukova in her paper "The Narrowed Field of Vision in A. Chekhov's Fiction" refers to such scientists as A.P. Chudakov, B.V. Tomashevsky, and V. Podoroga. The author proceeds from the understanding of spatial organization as an element of artistic reality that embodies the visual in fiction. E.L. Suzryukova points out the connection between the concept of the visual and the state of the observer, the sphere of axiology, and the system of characters. She writes that vision is inextricably linked with space. Therefore, when one's vision is narrowed, it denotes a closed space, the very structure of which implies a restricted line of sight. However, Chekhov's poetics is so complex that the narrowing of the vision can occur both in closed and in open space. Thus, not only the external environment is important: so is internal state of the observer. In addition, the narrowing of the field of vision can occur both in real and in mental space [10. P. 42]. The following definition has officially entered the dictionary of "Poetics" compiled by S.P. Lavlinsky and N.M. Gurovich: "The visual in fiction is defined as one of the most significant properties of artistic imagery that depend on the author's orientation both on individual visual associations of the reader and on the concretization of the object-type levels (R. Ingarden) of the inner world of the work of fiction as a whole" [11. P. 37].

\section{The meaning of the term "Unbestimmtheitsstelle" in the works of Roman Ingarden}

R. Ingarden distinguishes two types of uncertainty points: 1) those that can be removed, since the text has some detail; 2) those points of uncertainty that can not be eliminated, since the text does not contain any explanations for them. Analyzing the death of Tristan, R. Ingarden agrees that any details of how the death came slowly or suddenly - would be superfluous for artistic representation. The lack of details is what makes the work so tragic. We understand that non-expression (voids) are used in this case as an element of the structure of a work of art.

Literally, we are talking about the fact that places of incomplete certainty can be found in any part of the text that prevents the clarification of any property of 
a person, object or circumstances (the state of affairs): "Eine Unbestimmtheitsstelle ist überall dort aufzufinden (marked by us. - A.A.), wo man eine Eigenschaft einer Person, eines Gegenstandes oder einer Sachlage nicht feststellen kann, da sie im Text nicht genannt wird" [12. P. 49].

Why it is important to note: the art world itself, by its nature, hides some details, that is, it has non-visual parts that are auf-zu-finden, that is, are in potential (do not allow themselves to be discovered) and are currently hidden. Therefore, the existence of an aesthetic object is multiple: on the one hand, due to points of uncertainty, and on the other - due to concretization. The reader actualizes potential components by imagining objects in such situations and aspects as are indicated in the work of art. In other words, actualization is the concretizing elimination of points of uncertainty in the course of reading.

The visual in literature is given to the reader indirectly, through the eyes of the narrator or the eyes of the hero, the lyric subject, etc. Therefore, the receptive act somehow interacts with the axiological sphere of the depicted world. The type of value relationship that is expressed through a visible image that appears to the reader as a real detail of appearance or space, coming from the emotionalvolitional attitude of the hero, narrator or narrator is a visual distance.

The cases in which the visual is eliminated (reduced) we associate with the discovery of "places of incomplete certainty" by R. Ingarden inherent in a literary work. These places include not only visual images, but also images of sound, sensation, taste, and aroma, which the reader also imagines. Therefore, within the framework of the problem of the visual, we touch upon the phenomenon of visual reduction. Accordingly, the term "reduction of the visual" is intended to indicate the elimination of a specific imaginary sphere of the artistic world, which is narrower than all the "places of incomplete certainty", but is also part of the creative plan and a necessary condition for the existence of the artistic world.

Concretization is the result of the interaction of the work and the reader during the reading process. In each case, the concretization of the work is carried out at the moment of contemplation of the aesthetic object. So, R. Ingarden notes that in the process of concretization, aesthetic value is created. Consequently, concretization acts not only as perception, but also as co-creation itself.

For the first time, he addresses the points of uncertainty in the work "Das literarische Kunstwerk: Mit einem Anhang: Von den Funktionen der Sprache im Theaterschauspiel" in the seventh chapter "Die Schicht der dargestellten Gegenständlichkeiten", dedicated to the analysis of the layers of objects presented to the reader's attention.

It is important to understand that "schematicity" does not mean comprehensive certainty (unambiguity) of images in the work. If all components had comprehensive certainty, there would be no potentials for "places of incomplete certainty".

The intensity or the reduction of the visual in literature is caused by the nature of the visual and is determined not only by what is visible, but also by what is hidden from eye. Roman Ingarden discovered a previously unknown problems "Unbestimmtheitsstelle" and tasks of phenomenology and literary theory. Is not easy to explain his view concerning the tasks of dynamic types of artistic image and used his complicated terms. Some who hears this topic has a certain expectation, that considered to be the types of artistic images in question supposedly lies in its decisive 
over the right form of narratives, but for now we are talking about the correct form of reading. In other words, we did not seek to use sharper, or more favorable arguments to "pro et contra" Ingarden's discoveries. It is much more important to point out their potential - it is called to heighten the reflection that happens in the reading process.

\section{The actualization of visual potentials in practice}

B. Pasternak once gave a brief but consistent image of a man waiting in a hospital with rain pouring outside: "He was not allowed to go to her. Biting his bent finger till it bled, he went to the window, outside which oblique rain poured down, the same as yesterday and the day before. A hospital nurse came out of the ward. The squealing of a new-born could be heard from there" [13]. The emotional state of the personage is transmitted without words and sounds via the description of his posture. His emotional stress is clear from the way he went to the window to get some solitude and the way he tried to suppress his emotions by biting his finger. The severity of the stress is clarified by further details: biting his bent finger till it bled. After that, the reader's mental eye follows the hero's gaze, and we see the same slanting rain outside. The unchanging state of nature - it is raining now the way it did yesterday and the day before - is opposed to the tension of the moment and his overwrought angst. The expressive pose compensates for the lack of sound in the description. The silence, undisturbed by the constant rain, serves as the background for the main event: the squeak of the new-born baby. Still, the sound is preceded by a visual premonition: a nurse comes out of the ward. Her appearance means marks the end of his long waiting, and the opened door makes it possible to hear the new-born's cry.

The real space refers here to the artistic world, which is real both for the personage and the reader but in different ways. In the present research we believe that the expansion or contraction as a legitimate mobility of the viewpoint in fiction never happens by chance and is inherent to the narrator. Consider the following excerpt from Yu. Olesha's novel "Envy": "The clouds were floating across the sky and across the window glass, and in the glass their paths entwined". In the comparison "in the sky - in the glass" the distant is described through the close and vice versa. The paths of the clouds get entangled in the glass, which means that the close and the distant are combined, which is very important for understanding the features of the novel given through the narrator's eyes. The close (glass) and the distant (clouds) are depicted in close relationship to characterize the narrator. This indicates that the narrator can see similarities between opposites, which brings him closer to the author's outlook. Nikolai Kavalerov, a personage of Olesha's "Envy", describes another personage, Babichev, in the following way: "...he, like a fakir, can be in ten places at the same time" [14]. The narrator describes Babichev's ability to overcome the distance as a miracle. The simile indicates something magical, inaccessible, and fantastical. Comparisons and metaphors used by Kavalerov are often related to something exotic and fantastical. Thus, his view of the depicted world is reflected in the descriptive language. By comparing Babichev with a fakir, the narrator performs a "translation" from the language of everyday life into the language of poetry, which is inherent to his mind. 
The categories of "the close" and "the distant" are often axiological, but this does not mean that the distant is always considered as positive and the close - as negative, or vice versa. The world seen through the wrong side of the binoculars is often assessed as beautiful. However, the opposite effect can be observed when the spatial remoteness of the object makes it frightening and strange, like in the following excerpt: "A bell rang in the church, invisible from the balcony $<\ldots>$ He curled in the midpoint $\langle\ldots>$ the mysterious musician, indistinguishable, black, and, probably, as ugly as Quasimodo <... so terrible did the distance make him" [14].

The close or the distant are not axiological categories: it is the nature of the visual concretization in the conditions of the outlook that is axiological. In this and other cases, the narrator describes the characters differently, and his eye sees as much as his author-given axiological position allows him to.

\section{Conclusion}

First, the limits to the personage's outlook are found in the "slips of the tongue" they make and do not notice. However, these "slips of the tongue" are obvious to the reader, and the personage reveals himself or herself as an element of the system of the artistic world order. Second, the boundaries of the author's outlook are indicated by the choice of a particular system of characters, their words, and portraits, both verbal and external. According to R. Ingarden, the individuality of the reader's consciousness, in which the artistic image finds itself, is forced to enter into the concretization of the visually represented, or depicted, world.

For the reader, the eventfulness of the artistic vision is not mundane but aesthetic. The eventfulness happens due to the artistic vision. The reader and the author are the subjects of such an eventual vision due to their outsideness. The personages, observers, and narrators have a live presence in the depicted world. They do not see the place they occupy in the world order the way the reader sees it.

This place is always visually marked with an appropriate perspective. We believe that this perspective corresponds to the type of world order depicted in the text (the literary genus and the mode of fiction). Actualization of the visual in fiction allows potential states of the aesthetic object to acquire their eventfulness. The literary genre is a special condition for the receptive act to happen: it is the rules that guide the reader's imagination. The receptive acts of visual concretization are not predicted in advance in terms of perception. However, the contours of the playing ground where the reader, author, narrator, and heroes interact are a priori defined in terms of presentation and understood according to the literary genus. Each literary genus makes sense in its own way, i.e. the field of vision that is open to the reader and on which all receptive acts are played out.

Of course, the reader's outsideness to the visible artistic world contributes to their involvement into the aesthetic event. The personages can never be involved in the event since the boundaries of their existence make them different from real people. The reader's post-reflection on the book does not cancel those unique discoveries that occurred during the reading process. Therefore, the outlook and the environment of the personages, their viewpoints, and the types of images retain their aesthetic impact and are visually stable and reproducible. 
The visual in fiction is the dynamic types of the image structure that occur in the process of actualizing of potential states (R. Ingarden) in the receptive act of the reader's consciousness. The realization is not limited to the image of space but refers to the architectonic connections. While studying the visual in fiction, one encounters a bidirectional movement from reception to axiology and from axiology to reception: when we cease to notice the letters as such and allow the meaning of what is to emerge.

\section{References}

[1] Dyubo, Z.-B. (1976). Kriticheskie razmyshleniya o Poezii i Zhivopisi [Critical reflections on poetry and painting]. Moscow, Iskusstvo Publ. (In Russ.)

[2] Lessing, G.E. (1953). Izbrannye proizvedeniya [Selected works]. Moscow, Hudozhestvennaya literatura Publ. (In Russ.)

[3] Gadamer, G.G. (1991). Aktual'nost' prekrasnogo [The relevance of beauty]. Moscow, Iskusstvo Publ. (In Russ.)

[4] Iser, W. (2004). Izmenenie funktsii literatury. Protsess chteniia: Fenomenologicheskii podkhod [Changing the functions of the literature. Reading process: A phenomenological approach]. Sovremennaia literaturnaia teoriia [Modern literary theory]: Anthology. Moscow, Nauka Publ. (In Russ.)

[5] Mitscherling, J. (1985). Roman Ingarden's 'The Literary Work of Art': Exposition and Analyses. Philosophy and Phenomenological Research, 45(3), 351-381.

[6] Bahtin, M.M. (1979). Estetika slovesnogo tvorchestva [Aesthetics of verbal creativity] Moscow, Iskusstvo Publ. (In Russ.)

[7] Bakhtin, M.M. (1975). Voprosy literatury i estetiki. Issledovaniya raznykh let [Questions of literature and aesthetics. Studies of different years]. Moscow, Khudozhestvennaya literatura. (In Russ.)

[8] Asmus, V.F. (1968). Chtenie kak trud i tvorchestvo [Reading as work and creativity] Moscow, Voprosy teorii i istorii estetiki Publ. (In Russ.)

[9] Fukson, L.Yu. (2007). Chtenie [Read]. Kemerovo, Kuzbassvuzizdat Publ. (In Russ.)

[10] Suzryukova, E.L. (2009). Suzhennoe pole videniya v hudozhestvennoj proze A.P. Chekhova [Narrowed field of vision in the artistic prose of A.P. Chekhov]. Sibirskij filologicheskij zhurnal [Siberian philological journal], (3), 42. (In Russ.)

[11] Lavlinskiy, S.P., \& Gurovich, N.M. (2008). Vizual'noe v literature [The Visual in Literature]. Poetika: Slovar' aktual'nykh terminov i ponyatiy [Poetics: The Dictionary of Current Terms and Concepts] (p. 37). Moscow. (In Russ.)

[12] Ingarden, R. (1972). Die Schicht der dargestellten Gegenständlichkeiten. Das literarische Kunstwerk: Mit einem Anhang: Von den Funktionen der Sprache im Theaterschauspiel. https://doi.org/10.1515/9783110938487.229

[13] Pasternak, B.L. (2010). Doctor Zhivago (R. Pevear, L. Volokhonsky, Trans.). Retrieved May 10, 2020, from http://www.rulit.me/data/programs/resources/html/Pasternak_Doctor_ Zhivago_RuLit_Net_231118.html.zip

[14] Olesha, Yu.K. (2017). Zavist'. Zagovor chuvstv. Strogij yunosha [Envy. The conspiracy of feelings. Strict boy]. Saint Petersburg, Vita Nova Publ. (In Russ.)

\section{Article history:}

Received: 18 May 2020

Revised: 25 May 2020

Accepted: 30 May 2020 


\title{
For citation:
}

Aksenova, A.A. (2020). Dynamic types of artistic image: Roman Ingarden's phenomenology and literary theory. RUDN Journal of Studies in Literature and Journalism, 25(3), 487-496. http://dx.doi.org/10.22363/2312-9220-2020-25-3-487-496

\section{Bio note:}

Anastasia A. Aksenova, Master of Philosophy, lecturer and researcher in the field of linguistics and literary studies, junior researcher of the Research and Innovation Department of the Kemerovo State University. E-mail: AA9515890227@yandex.ru

\section{Динамические виды образной структуры: взгляд на феноменологический подход Романа Ингардена с позиций теории литературы}

\author{
А.А. Аксенова \\ Кемеровский государственный университет \\ Российская Федерачия, 650000, Кемерово, ул. Красная, 6
}

\begin{abstract}
Аннотация. Статья посвящена осмыслению некоторых данных, полученных польским философом Романом Ингарденом, в области изучения литературного произведения, эстетики, принадлежащим к феноменологическим исследованиям. Развитие идей Ингардена рассматривается с привлечением русских авторов, которые редко трактуются в феноменологической эстетике. Динамические виды образной структуры - это те качества потенциальных состояний, которые выступают и актуализируются в восприятии читателя как проблема воображения и художественного (визуального) образа. Таким образом, динамический характер видов образной структуры - это переход от нетематического фона к его актуальному состоянию и обратно. Реконструкция тезисов Ингардена приводит, в частности, к фрагментам работы, в которых он анализирует проблему зримо представленного пространства. Для изучения визуального в художественной литературе нужно понимать, что встреча читателя с литературным произведением актуализирует потенциальные типы, которые, по словам Р. Ингардена, «сверкают и гаснут». Визуальная природа эстетического объекта напрямую зависит от того, какое из этих потенциальных состояний актуализируется. Изучение визуального в художественной литературе предполагает двунаправленное движение от рецепции к аксиологии и от аксиологии к рецепции.
\end{abstract}

Ключевые слова: эстетический объект, рецептивный акт, художественный мир, читатель, виды образной структуры, воображение, представление, Б. Пастернак, Ю. Олеша

\section{Список литературы}

[1] Дюбо Ж.-Б. Критические размышления о Поэзии и Живописи. М.: Искусство, 1976. $767 \mathrm{c}$.

[2] Лессинг Г.Э. Избранные произведения М., 1953.

[3] Гадамер Г.-Г. Актуальность прекрасного. М.: Искусство, 1991. 367 с. 
[4] Изер B. Изменение функций литературы. Процесс чтения: феноменологический подход // Современная литературная теория: антология. М.: Флинта; Наука, 2004.

[5] Mitscherling $J$. Roman Ingarden's 'The Literary Work of Art': Exposition and Analyses // Philosophy and Phenomenological Research. 1985. Vol. 45. No. 3. Pp. 351-381.

[6] Бахтин М.М. Эстетика словесного творчества. М., 1979.

[7] Бахтин М.М. Вопросы литературы и эстетики. М., 1975.

[8] Асмус В.Ф. Чтение как труд и творчество // Асмус В.Ф. Вопросы теории и истории эстетики. М., 1968.

[9] Фуксон Л.Ю. Чтение / ГОУ ВПО «Кемеровский государственный университет». Кемерово: Кузбассвузиздат, 2007. 223с.

[10] Сузрюкова Е.Л. Суженное поле видения в художественной прозе А.П. Чехова // Сибирский филологический журнал. 2009. № 3. С. 42.

[11] Лавлинский С.П., Гурович Н.М. Визуальное в литературе // Поэтика: словарь актуальных терминов и понятий. М.: Изд-во Кулагиной; Intrada, 2008. С. 37-39.

[12] Ingarden R. Die Schicht der dargestellten Gegenständlichkeiten // Das literarische Kunstwerk: Mit einem Anhang: Von den Funktionen der Sprache im Theaterschauspiel. 1972. https://doi.org/10.1515/9783110938487.229

[13] Пастернак Б.Л. Доктор Живаго / пер. на англ. Р. Певера, Л. Волохонской. 2010. URL: http://www.rulit.me/data/programs/resources/html/Pasternak_Doctor_Zhivago_ RuLit_Net_231118.html.zip (дата обращения: 10.05.2020).

[14] Олеша Ю.К. Зависть. Заговор чувств. Строгий юноша. СПб.: Вита Нова, 2017. 624 с.

\section{История статьи:}

Дата поступления в редакцию: 18 мая 2020 г.

Дата принятия к печати: 30 мая 2020 г.

\section{Для цитирования:}

Aksenova A.A. Dynamic types of artistic image: Roman Ingarden's phenomenology and literary theory // Вестник Российского университета дружбы народов. Серия: Литературоведение. Журналистика. 2020. Т. 25. № 3. С. 487-496. http://dx.doi.org/10.22363/ 2312-9220-2020-25-3-487-496

\section{Сведения об авторе:}

Аксенова Анастасия Александровна, магистр философии, преподаватель-исследователь по направлению «Языкознание и литературоведение», младший научный сотрудник научно-инновационного управления Кемеровского государственного университета. E-mail: AA9515890227@yandex.ru 